The American Journal of Social Science and Education Innovations

(ISSN - 2689-100x)

VOLUME 04 ISSUE 01 Pages: 5-8

SJIF IMPACT FACTOR (2020: 5. 525) (2021: 5. 857)

OCLC - 1121105668 METADATA IF -8.106

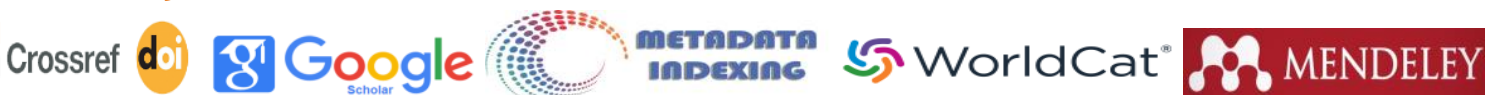

Research Article

\title{
ENGLISH AS A GLOBAL LANGUAGE IN XXI CENTURY
}

Submission Date: December 21, 2021, Accepted Date: January 02, 2022,

Published Date: January 12, 2022 |

Crossref doi: https://doi.org/10.37547/tajssei/Volume04lssue01-02

Journal Website: https://theamericanjou rnals.com/index.php/ta jssei

Muqaddam Ibrohimova

EFL teacher of Namangan State University, Uzbekistan

Copyright: Original content from this work may be used under the terms of the creative commons attributes 4.0 licence.

\section{Sevara Ziyaboyeva}

EFL teacher of Namangan State University, Uzbekistan

\section{ABSTRACT}

English is currently described in many different ways: as "world language", "global language", "lingua franca", "connected language", etc. This article highlights the role of English that is being taught from three perspectives, namely as a first or native language (L1), a second language (L2), as a foreign language (FL) and some challenges as a global language.

\section{KEYWORDS}

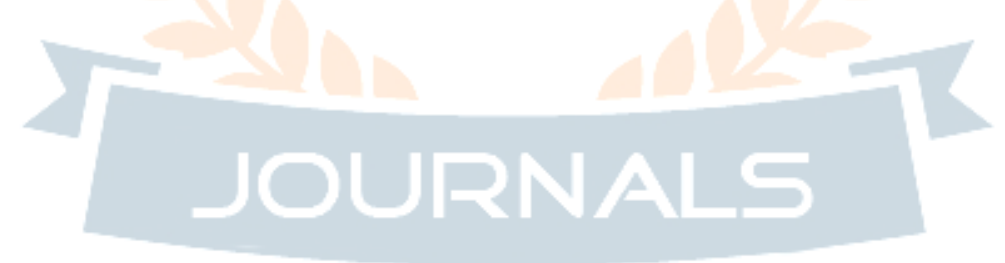

English, global language, lingua franca, second language, foreign language, inner circle, the outer circle, the expanding circle.

\section{INTRODUCTION}

In the age of globalization, English is playing a key role in job opportunities, international mobility, and access to information. There is evidence that the widespread love of learning English and adaptation to the so-called Western way of life prevents the development of local cultures and languages. Moreover, students face 
The American Journal of Social Science and Education Innovations (ISSN - 2689-100x)

VOLUME 04 ISSUE 01 Pages: 5-8

SJIF IMPACT FACTOR (2020: 5. 525) (2021: 5. 857)

OCLC - 1121105668 METADATA IF - 8.106

Crossref
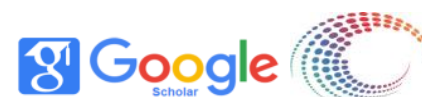

metapata

(5) WorldCat"

Publisher: The USA Journals

educational challenges, as they have to study the content of the discipline in a language that they may not know very well.

Currently people use 6809 living languages across the world and about 100 languages to facilitate social interaction. In the XXI century, communication has been greatly improved through the widespread distribution of media, computers and mobile phones. The Internet is fast becoming the information highway of choice, satisfying our need for communication and important business deals and negotiations are carrying out in English.

\section{MATERIALS AND METHODS}

If we talk about teaching English, it should be noted that English has become an international language that has an impact overall world. It is estimated that $1 / 6$ of the world's population speaks or uses English for work and communication. In addition to being the language of communication, English is also the primary language of the UN and NATO, the official language of international aviation, the unofficial language of sports, radio broadcasts, written correspondence, rapidly evolving technology, scientific research and literature.

Currently, English is taught from three perspectives, namely as a first or native language ( $L 1)$, a second language (L2) and as a foreign language (FL). Braj Kachru describes these three perspectives as the inner circle, the outer circle, and the expanding circle in his article. In the inner circle, English is taught and used as the first or mother tongue (lingua franca). It includes the United Kingdom, the United States of America, Canada, Australia and New Zealand. In the outer circle, English is taught and used as a second language. This is happening in countries such as India, Nigeria, Malaysia, Tanzania and many others as a consequence of British colonization. In these countries, English is used in parallel with their mother tongue. As a second language, English is considered to be the main language in commerce, administration and education. In an expanding circle, English is taught and used as a foreign language. They are countries like Russia, China, Spain, Saudi Arabia, Uzbekistan and many other countries where English is considered the main language of international news, culture and education at all levels. English as a second language, is represented by four different groups. First of all, English is the main language of the mass media, i.e. the language of newspapers, radio and television. In addition, English is the language of official institutions such as courts and government. Moreover, it is the language used in educational institutions. English is considered a major component of commercial and industrial organizations. In the outer circle, having a strong knowledge of English as a second language provides people with a smooth transition to social and economic development. English as a second language is learned not only in the outer circle, but also in the inner circle. Immigrants in the United Kingdom, the United States, Canada, Australia are learning English for integration that will allow them to identify with their native language in their home country and use English as an intermediary language when communicating with people from other language families.

When it comes to learning a language as a foreign language, there is an assumption that people learn it for two purposes. On the one hand, they study a foreign language with a "technical" (auxiliary) purpose. This group of learners consists of tourists, vendors and students. They need a foreign language in order to read books in the target language and communicate with native speakers of this language. On the other hand, some people study a foreign 
The American Journal of Social Science and Education Innovations (ISSN - 2689-100x)

VOLUME 04 ISSUE 01 Pages: 5-8

SJIF IMPACT FACTOR (2020: 5. 525) (2021: 5. 857)

OCLC - 1121105668 METADATA IF - 8.106

\section{Crossref $d$}
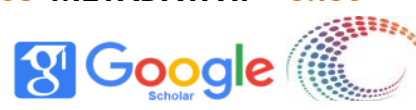

metapenta

(5) WorldCat"

Publisher: The USA Journals

language for the purpose of integration. Students of this group have the goal of identifying with the speech community of the target language. Knowing the language, they feel at home and understand the attitude and worldview of that speech community. According to Broughton, Brumfit, Flavel and Hill, in contrast to English as a second language, English as a first language is taught only at school and has nothing to do with the life of the student community.

Recently, the more English occupies the big role of a global language, the thinner the line between L2 (English as a second) and L1 (native English) becomes. In addition, the status of English has changed in many countries. For example, the decline in the importance of English in countries such as India, Sri Lanka has led to the fact that English is presented more as an FL than an L2. At the same time, we see the reverse process in other countries. For example, in many European countries, there is a process of transition of the English language from the status of FL to the status of $L 2$.

Whether it's L1, L2 or FL, it is argued that the emergence of English as a global language has had a huge impact on the entire concept of language learning. For Broughton, Brumfit, Flavel and Hill, English or the language of a "neighboring" country, or the language of global significance that educators devote more hours to learning than any other language or subject in the curriculum. Regardless of the methodology used in language classes and the setting in which teaching is carried out around the world, all noteworthy language classes are based on basic principles that are reflected in the interaction of all aspects that contribute to the connection of theory and practice in learning English as an FL.

Along with the development of English as a world language, we learn about some of the features that a world language should have. Regardless of the origin, it should be a language that is practical and beneficial, which can cover the needs of everyone. Although English was originally the language of the British, today there are many varieties of it, including American, African, Indian and Australian English. In addition, the English language now brings together the dreams, aspirations of many peoples, as well as the experiences of different countries. It is used to convey a huge mass of various information, whether it be the latest advances in science and technology, enrichment of the experience of an ethnic group, or business negotiations; in the documentation of cultural characteristics; in an individual experience. Its vocabulary has been significantly enriched with new words borrowed from other languages of the world. Over time, it becomes obvious that the global language will change beyond recognition, as is the case with the English language.

About ten thousand words borrowed from Hindi and other Indian languages have become part of the Indian English language. These include: guru, babu, chorpoy, curry, etc. We are very familiar with the following commonly used Pidgin words: lathi-charge (the phenomenon in which a group of policemen run after someone with a police baton), rickshaw-wall (a small two-wheeled cart for one passenger, harnessed by one person), double-roti (bread), etc. [Oxford ... 1997].

As a global language, English faces many challenges. Spoken English varies from region to region according to the cultural and linguistic differences of the local people. Similarly, written English is also very different lexically, in form and structure, since the language is primarily the bearer of its thought and "scheme". Consequently, the English language used by an African is not the same as the language of an Australian. The impact of electronic SMS also affects English spelling and grammar. The issues of "clarity" and 
The American Journal of Social Science and Education Innovations (ISSN - 2689-100x)

VOLUME 04 ISSUE 01 Pages: 5-8

SJIF IMPACT FACTOR (2020: 5. 525) (2021: 5 . 857)

OCLC - 1121105668 METADATA IF - 8.106

Crossref dol gi Google

perspectives, namely as a first or native language (L1), a second language ( $\mathrm{L} 2)$ and as a foreign language (FL).

\section{REFERENCES}

1. Abbott G. W. Intelligibility and Acceptability in Spoken and Written Communication // ELT J 1979. xxxiii (3). Pp. 168-175.

2. Crystal, D. (1987). The Cambridge Encyclopedia of English Language. Cambridge University Press, Cambridge,

3. Crystal, D. (1997). English as a Global Language. Cambridge: Cambridge University Press.

4. Crystal, D. (2019). The Cambridge Encyclopedia of English Language. Cambridge: Cambridge University Press.

5. McArthur T. The Oxford Guide to World English. Oxford: Oxford University Press, 2002.

To summarize, we would like to point that the emergence of English as a global language has had a huge impact on the entire concept of language learning as English is being taught from three 